DOI: 10.31392/NPU-nc.series14.2019.27.13

УДК 378:011.3-051:78

Джумеля А. 3.

\title{
Евристичні методи формування художньо-образного сприйняття майбутніх учителів музичного мистецтва та хореографії
}

\begin{abstract}
На основі вивчення наукових праць і наявного педагогічного досвіду розробленні евристичні методи навчання, спрямованні на формування художньо-образного сприйняття майбутніх учителів музичного мистецтва в процесі фахового навчання у вищому педагогічному навчальному закладі. Використання евристичних методів у процесі формування художньо-образного сприйняття студентів факультетів мистецтв педагогічних університетів здійснювалося комплексно під час проведення музично-педагогічної практики майбутніх учителів музичного мистецтва та хореографії зі школярами. Серед ефективних евристичних навчальних методів виокремлені: методи активізації сприйняття учнів на уроках музичного мистецтва; метод розуміння причинно-наслідкових зв'язків; метод відповідних вирішень творчих завдань; індуктивний метод встановлення причинно-наслідкової залежності вибору навчального матеріалів для залучення школярів до пластичного інтонування та використання навчальної наочності; метод вироблення емоційно-оцінних реакцій на сприйняття мистецьких творів та ін. За наявних умов передбачена ефективність використання евристичних методів навчання у процесі формування художньообразного сприйняття студентів факультетів мистецтв педагогічних університетів та в їх майбутній музично-педагогічній діяльності.
\end{abstract}

Ключові слова: майбутні вчителі музичного мистецтва та хореографії; художньо-образне сприйняття; евристичні методи.

Зміни в педагогічній теорії і практиці навчально-виховного процесу в мистецьких вищих навчальних закладах спрямовані на стимулювання студентів до набуття фахових компетенцій і надання їх самостійній роботі творчого, проблемного, дослідницького характеру. Слід підкреслити, що кожний наступний рік нового століття все більше стверджує думку про те, що ми знаходимося на порозі нової епохи, що має зовсім нові якісні характеристики у всіх галузях життєдіяльності людини. У зв’язку з цим набуває актуальності проблема формування художньо-образного сприйняття майбутніх учителів музики i хореографії засобами пластичного інтонування, що забезпечує можливість емоційного впливу на учнів, прищеплення в них інтересу до музично-виконавської хореографічної діяльності, розширення мистецького світогляду.

Теоретичною основою осягнення художньо-образного змісту мистецьких творів слугують праці Б.Асаф'єва, Л.Баренбойма, Н.Ветлугіної, Н.Збруєвої, О.Сременко, А.Козир, Л.Масол, Г.Падалки, Я.Романчук, О.Ростовського, О.Рудницької, М.Румер, Б.Теплова, В.Федоришина, В.Яновської та ін.). Учені підкреслюють, що активне художньо-образне сприйняття мистецьких творів можливо лише в активній музично-творчій діяльності, де важливе місце займають музично-ритмічні рухи, зокрема пластичне інтонування - здатність осмислено, свідомо сприймати та виконувати твори мистецтва. В їх основі лежить інтонаційний початок, фонетична відповідність, темпоритм, синтаксична розчленованість, тому використання цієї паралелі у процесі фахового навчання студентів факультетів мистецтв педагогічних університетів доцільне й надзвичайно важливе.

Мето ю статті $є$ аналіз ефективності використання евристичних методів навчання у процесі формування художньо-образного сприйняття студентів факультетів мистецтв педагогічних університетів.

Завдання статті: розглянути можливості використання евристичних методів навчання у фаховому розвитку майбутніх учителів музичного мистецтва та хореографії; проаналізувати використання евристичних методів навчання у процесі формування художньо-образного сприйняття студентів факультетів мистецтв педагогічних університетів; розглянути вплив використання евристичних методів навчання на процес формування художньо-образного сприйняття майбутніх учителів музичного мистецтва та хореографії засобами пластичного інтонування. 
Виклад основного матеріалу. Перевірка ефективності використання евристичних методів навчання у фаховому розвитку майбутніх учителів музичного мистецтва та хореографії проходила під час проведення педагогічної виробничої практики в умовах загальноосвітньої школи. 3 метою залучення студентів до аналітично-операційної діяльності ми використали евристичні методи. Комплекс таких методів передбачав забезпечення студентів факультетів мистецтв умінням використовувати евристичний підхід під час активізації художньо-образного сприйняття учнів на уроках музичного мистецтва та у позаурочній роботі в умовах роботи вокально-хореографічного ансамблю. При цьому слід було враховувати те, як саме учні сприймають дані під час повідомлення їх вчителем, сприймають музику і демонстрацію студентом правильного показу музичного твору. Ці види навчальної діяльності школярів нами було враховано під час залучення студентів до навчальної діяльності над виконанням творчих завдань. Комплекс евристичних методів включав використання студентами пояснювально-спонукаючого способу подачі навчальної інформації для активного художнього сприймання їі учнями.

Організація навчальної роботи студентів факультетів мистецтв передбачала їх умовний розподіл на три групи. 3 цією метою студентами були розроблені серії уроків, які об'єднані загальною темою. У першій групі студенти розробляють навчальні завдання евристичного спрямування для учнів певного шкільного віку. Це здійснюється для того, щоб студенти набули навичок та вмінь залучати учнів до інтерактивної навчальної роботи на уроках музичного мистецтва та у позаурочній роботі в умовах роботи вокально-хореографічного ансамблю. У другій групі студенти розробляють творчі завдання для залучення школярів до активного художньо-образного сприйняття музики. У третій групі студенти розробляють евристичні навчальні завдання для залучення учнів до спільної роботи на уроках музичного мистецтва та у позаурочній роботі в умовах роботи вокально-хореографічного ансамблю, що передбачає використання засобів пластичного інтонування. У навчальній роботі студенти факультетів мистецтв планують реалізацію частково-пошукових дій.

На наступному етапі за даними методами студенти поєднують результат навчальної діяльності, аналізуючи плани-конспекти уроків та позаурочних заходів. Ці розроблені уроки музичного мистецтва та плани позаурочної роботи у вокально-хореографічному ансамблі аналізуються, спільно обговорюються. Таким чином, організація навчальної діяльності студентів факультетів мистецтв за даними методами сприяє їх активізації під час аналітичної діяльності над навчальним матеріалом для розроблення творчих завдань евристичного спрямування, що передбачають набуття школярами вміння адекватно сприймати дані на уроках музичного мистецтва та у позаурочній роботі в умовах роботи вокальнохореографічного ансамблю. Евристичні методи сприяють створенню позитивних умов для набуття майбутніми вчителями музичного мистецтва та хореографії вміння щодо успішного вирішення творчих завдань із використанням інноваційних педагогічних технологій.

Доцільно зазначити, до евристичних методів навчання Г.Падалка відносить метод створення художніх образів, що передбачає залучення студентів до створення нового в мистецтві. Вчена наголошує: «Нехай творчі спроби учнів не містять художньої цінності, все одно сам процес створення того, що раніше не було в мистецтві, виявляється могутнім фактором їх спонукання до активного художнього самовираження. Мистецький образ втілює результат творчих дій автора. Залучаючи учня до творчості, педагог створює умови до осягнення внутрішніх закономірностей мистецтва, усвідомлення його творчої природи на рівні практичних дій» $[1,193]$.

Продовжуючи спонукати студентів до набуття вміння розробляти навчальну наочність для залучення учнів до художньо-образного сприйняття мистецьких творів засобами пластичного інтонування на уроках музичного мистецтва та у позаурочній роботі в умовах роботи вокально-хореографічного ансамблю, нами до розробленої методики був введений метод розуміння причинно-наслідкових зв'язків. За даним методом студенти факультетів мистецтв навчились критично ставитись до процесу самостійної роботи над музичним 
твором, відбувалось виховання у студентів здатності до оцінювання творів музичного мистецтва для доцільного застосування навчальної наочності. Цей метод передбачає чотири етапи навчальної роботи. На першому етапі «Визначення об'єкту» студентів залучали до виконання трьох завдань. Перше завдання постає у визначенні об'єкту для навчальної роботи, а саме: музичного твору з навчальної програми «Музичне мистецтво». До того ж студенти розглядають загальні питання щодо організації навчальної діяльності школярів під час вокально-хорової роботи над піснею, місце розташування учнів у навчальній ситуації визначають навчальний час для формування адекватного сприйняття учнів.

На другому етапі «Складові об’єкту» здійснюється фіксація окремих деталей, а також розглядаються загальні питання щодо організації навчальної діяльності учнів із використанням пластичного інтонування, та розроблення наочних засобів навчання. Продуктом даного етапу є складання плану організації цієї діяльності. На третьому етапі «Деталізація об'єкту» студенти розглядають кожен пункт плану з деталізацією. До того ж, студенти здійснюють часткове виготовлення наочних навчальних засобів та визначають їх використання на уроці відповідно створеному плану. Далі, на четвертому етапі за даним методом «Реалізація творчого задуму» викладач пропонує студентам розробити й використати нові оригінальні способи активізації учнів під час пластичного інтонування. Важливим на даному етапі постає залучення студентів до самооцінювання. Таким чином, за даним методом студенти навчаються встановлювати причинно-наслідкові зв'язки між етапами підготовки до проведення з учнями уроку музичного мистецтва та позаурочних заходів в умовах роботи у вокально-хореографічних ансамблях й здійснюють організацією цього процесу. Поряд із тим студенти факультетів мистецтв набувають уміння розробляти навчальну наочність для залучення учнів до активного сприйняття даних на уроках музичного мистецтва та у позаурочній роботі в умовах навчання в вокально-хореографічному ансамблі.

Як показує практика, вчитель музичного мистецтва та хореографії, залучаючи учнів до імпровізації під час пластичного інтонування на уроках музичного мистецтва, стикається 3 тим, що більшість учнів не володіють набором виконання елементарних жестів для того, щоб використати їх у навчальній діяльності над музичним твором. Метод відповідних вирімень передбачає забезпечення студентів факультетів мистецтв уміннями спонукати учнів до оволодіння набором елементарних рухів для активного самовиявлення під час сприйняття музичного твору. За даним методом доречно розподілити студентів на малі групи. Навчальне завдання постає у прослуховуванні певного музичного твору, визначенні музичного стилю. Далі, студенти переглядають необхідні відеоматеріали в мережі Інтернет, де здійснено відеозапис танцю під музику у відповідному стилі. На цьому етапі студенти факультету мистецтв мають відібрати фрагменти з декількох відеозаписів і розробити навчальні вправи для учнів, які передбачають їх забезпечення набором елементарних рухів із подальшим залученням до пластичного інтонування.

Враховуючи специфіку фахової підготовки майбутніх учителів музичного мистецтва та хореографії, ми визначаємо наступне завдання, що постають у виробленні у студентів факультетів мистецтв уміння добирати методи розвитку музикальності учнів. Ми виходили 3 того, що студенти, як правило, ознайомлюються з багатьма навчальними методами, однак не приділяють увагу їх призначенню. Метод змістовного бачення сприяє залученню студентів до аналізу відомих їм навчальних методів подальшого вибору ефективних методів розвитку музикальності учнів засобами пластичного інтонування [4]. 3 цією метою студентам слід запропонувати сформулювати критерії, за якими постане вибір доцільних навчальних методів для музично-педагогічної робот з учнями. Далі студенти факультетів мистецтв визначають завдання щодо залучення учнів до пластичного інтонування на уроках музичного мистецтва та у позаурочній роботі в умовах навчання у вокально-хореографічному ансамблі. Відповідно до цих завдань кожен студент заповнює бланк «Навчальна робота над методами залучення учнів до пластичного інтонування». За цих умов студент факультету мистецтв має умовно 
розподілити відомі навчальні методи на групи і таке угрупування передбачає визначення назви групи та призначення методів, які включено до певної групи. У процесі проведення цієї роботи необхідно залучати студентів до загального обговорення [2].

Продовжуючи розвивати вміння студентів факультетів мистецтв добирати методи розвитку музикальності учнів, ми застосовували відомий індуктивний метод. Цей метод уможливлює встановлення причинно-наслідкової залежності вибору навчального методу для залучення школярів до пластичного інтонування та використання навчальної наочності [5]. Навчальна робота за даним методом передбачає заповнення кожним студентом розробленої нами таблиці «Виявлення причинно-наслідкової залежності», до якої необхідно занести дані щодо назви навчального методу, назви навчальної наочності, яка використовується в цьому процесі. Для того, щоб заповнити графу «Додатковий засіб навчальної наочності», кожен студент має визначити «слабкі сторони» цього методу й запропонувати такий засіб навчальної наочності, котрий сприяє ефективній організації музично- творчої діяльності зі школярами на уроці музичного мистецтва та у позаурочній роботі в умовах навчання у вокально-хореографічному ансамблі.

Доцільно зазначити, що процес формування творчого сприймання майбутніх учителів музичного мистецтва та хореографії передбачає активізацію їх емоційної сфери. Такі процеси як відчуття, переживання активізуються завдяки цілеспрямованому впливу на емоційне мислення особистості і завдяки цьому збагачується емоційний досвід особистості, що здатна регулювати свій емоційний стан [6]. Під час творчого сприймання музичного твору студент має набути вміння оперувати набутими фаховими знаннями, вміннями, набутим комплексом відчуттів, вмінням фантазувати й уявляти, трансформувати дані згідно навчального завдання. Це зумовлюється необхідністю вироблення особистістю власного відношення до музичного звучання.

Метод вироблення емоційно-оцінних реакцій у майбутніх учителів музичного мистецтва та хореографії передбачає залучення їх до навчальної роботи над музичним твором 3 використанням засобів пластичного інтонування. Для того, щоб студенти засвоїли причиннонаслідувальні зв'язки між характером музичного образу та його виразним висловленням через рухи, ми застосували педагогічну технологію «Асоціативний кущ». Студенти факультетів мистецтв працювали за даним методом самостійно.

Викладач забезпечував кожного студента звукозаписом музичного твору. Кожен студент, використовуючи будь-який засіб мультимедіа та навушники, опрацьовує музичний твір із застосуванням знань знаково-графічної орієнтації, а саме нотації, фіксації ритму, сценографії, фіксації рухів під час пластичного інтонування тощо. Викладач забезпечує кожного студента таблицею «Самостійне опрацювання музичного твору», яку студент має заповнювати під час самостійної роботи над навчальним завданням. Останнє постає у виробленні студентом оцінного ставлення до певного музичного твору.

Спираючись на це, кожен студент розробляє два «Набори активного сприймання учнів», а саме для учнів молодшого та середнього шкільного віку. До такого набору входить: коротке повідомлення про музичний твір; музична гра, яка охоплює музичне звучання даного твору та залучення учнів до пластичного інтонування; творче завдання для учнів під час слухання музики.

Висновки. Отже, оволодіваючи певними навчальними методами майбутні вчителі музичного мистецтва та хореографії навчаються інтенсифікувати процес оволодіння учнями навичками художньо-образного сприйняття творів мистецтва, спонукати їх до музичнотворчої діяльності. У цьому процесі використання евристичних методів відіграє велике значення, адже така робота спонукає їх до творчості, що загалом $\epsilon$ ефективним для формування художньо-образного сприйняття мистецьких творів.

\section{Література}

1. Падалка Г.М. Педагогіка мистецтва (Теорія і методика викладання мистецьких дисциплін) К. : Освіта України. 2008. - 274 с. 
2. Олексюк О. М., Ткач М. М. Музично-педагогічний процес у вищій школі. Київ : Знання України, 2009. $123 \mathrm{c.}$

3. Топчієва І.О. Шляхи евристичного навчання майбутніх учителів музики / I.О. Топчієва // Науковий вісник Чернівецького ун-ту: зб. наук. праць. - Чернівці: ЧНУ, 2009. - Вип. 491. - С. 168175.

4. Эвристическое обучение : В 5 т. Научные основы / Под ред. А. В. Хуторского. Москва : ЦДО «Эйдос», 2011. Т. 1.

5. Nierman G.E. The role of private music instruction in the development of high school music student's ability to describe musical events // Bull. Council Res. Music Education. - 1983. - №73. - P.15-27.

6. Taylor C. W. Various approaches and definitions of creativity / C.W. Taylor ; R. Sternberg (ed.) // The nature of creativity. - Cambridge : Cambr. Press, 1988. - P. $99-126$ c.

\section{Про автора:}

Джумеля Андріана Зеновіївна, викладач кафедри хореографії факультету мистецтв імені Анатолія Авдієвського, Національний педагогічний університет імені М.П. Драгоманова; ORCID: 0000-0003-1863-8507

\section{Heuristic methods for forming the art perceptions of future teachers of music and choreography}

Relevance of the study. Changes in the pedagogical theory and practice of the educational process in art higher education institutions are aimed at stimulating students to acquire professional competencies, and giving them independent work of creative, problematic and research character. It should be emphasized that each year of the new century, we are increasingly asserting that we are on the threshold of a new era, which has completely new qualitative characteristics in all areas of human life. In this connection, the problem of formation of artistic and figurative perception of future music teachers and choreography by means of plastic intonation, which provides the opportunity for emotional influence on students, instilling in them interest in music-performing choreographic activity, expansion of artistic world outlook becomes more relevant.

Aim and Objectives. The purpose of the article is to analyze the effectiveness of the use of heuristic teaching methods in the process of formation of artistic and figurative perception of students of the faculties of arts of pedagogical universities. Objectives of the article: To consider the use of heuristic teaching methods in the professional development of future teachers of music and choreography; to analyze the use of heuristic methods of teaching in the process of forming artistic and figurative perception of students of the faculties of arts of pedagogical universities; to consider the influence of the use of heuristic teaching methods on the process of formation of artistic and figurative perception of future teachers of music art and choreography by means of plastic intonation.

Research methods. The article investigates the effectiveness of the introduction of heuristic teaching methods for the formation of artistic and figurative perception of students of the faculties of arts of pedagogical universities. On the basis of the study of scientific works and the available pedagogical experience, heuristic methods of teaching are directed to the formation of artistic and figurative perception of future teachers of music art in the process of professional education in a higher pedagogical institution.

Results. The use of heuristic methods of teaching in the process of forming the artistic and figurative perception of students of the faculties of arts of pedagogical universities was carried out in complex during the conduct of music-pedagogical practice of future teachers of music and choreography with students. Among the effective heuristic teaching methods are the following: methods of activating students' perceptions in music lessons; a method of understanding cause and effect relationships method of appropriate solutions of creative problems; inductive method of establishing the cause and effect dependence of the choice of educational materials for involving schoolchildren in plastic intonation and use of educational clarity; a method of producing emotional-evaluative reactions to the perception of works of art, etc. The complex of heuristic methods envisaged to provide students of the faculties of arts with the ability to use the heuristic approach in activating the students' artistic perception in the lessons of musical art and in extracurricular work in the conditions of work of the vocal-choreographic ensemble.

Conclusions. Under the available conditions, the effectiveness of the use of heuristic teaching methods is envisaged in the process of formation of artistic and figurative perception of students of the faculties of arts of pedagogical universities and in their future musical and pedagogical activity.

Keywords: future teachers of music and choreography; artistic perception; heuristic methods. 


\section{References}

1. Padalka H.M. Pedahohika mystetstva (Teoriia i metodyka vykladannia mystetskykh dystsyplin). K. : Osvita Ukraina. 2008. - 274 s. [in Ukrainian].

2. Oleksiuk O. M., Tkach M. M. Muzychno-pedagogichny process u vyshij shkoli. Kyiv : Znania Ukrainy, 2009. 123 p. [in Ukrainian].

3. Topchieva I.O. Ways of heuristic education of future music teachers. Scientific Bulletin of Chernivtsi Univ. Sciences. wash. - Chernivtsi: CNU, 2009. - Issue. 491. - pp. 168-175. [in Ukrainian].

4. Heuristic training: 5 t. Scientific basis / Ed. A.V. Khutorsky. Moscow: Central Eidos Center, 2011.V. 1. [in Russian].

5. Nierman G.E. The role of private music instruction in the development of high school music student's ability to describe musical events // Bull. Council Res. Music Education. - 1983. - №73. - P.15-27.

6. Taylor C. W. Various approaches and definitions of creativity / C.W. Taylor ; R. Sternberg (ed.) // The nature of creativity. - Cambridge : Cambr. Press, 1988. - P. $99-126$ c.

About the author:

Dzhumelia Andriana Zenoviivna, lecturer at the Choreography Chair (Faculty of Arts), National Pedagogical Dragomanov University (Kyiv, Ukraine); ORCID: 0000-0003-1863-8507 